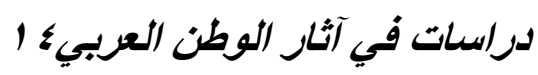

\title{
Representations of a Goddess Suckling a King in Ancient Egypt
}

\section{Tarneem Farag Bayoumi* \\ Riham M. Ezz El-din** \\ Abstract}

Representations of a goddess suckling a king occur in Egyptian art as early as the Old Kingdom, and they continue throughout Egyptian history. They are concerned with an event which was preserved in scenes as well as in statuary. These representations seem to symbolize the nurturing relationship of mother and child. Also, they might symbolize the ruler's rebirth in the Afterlife. This paper will provide an overview of historical literature in ancient Egypt that presents breastfeeding as a constitutive substance of kingship relatedness where it shows royals nursing at the breasts of goddesses conferring upon them divine status and bolstering their royal legitimacy. The paper will start by a general introduction of breastfeeding in ancient Egypt and words in ancient Egyptian language related to suckling and nursing, followed by examples of representations of goddesses suckling a pharaoh in Ancient Egypt arranged in a chronological order. The study aims at analyzing and understanding these representations, identifying the most important goddesses which appeared in this context, it also sheds light upon the religious significance and occasions of these representations.

\footnotetext{
* Lecturer at the High Institute of Tourism and Hotels, El- Seyouf. Alexandria.

** Lecturer at the High Institute of Tourism and Hotels, EGOTH, Guiding Department, Alexandria.
} 


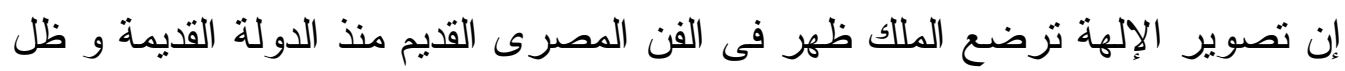

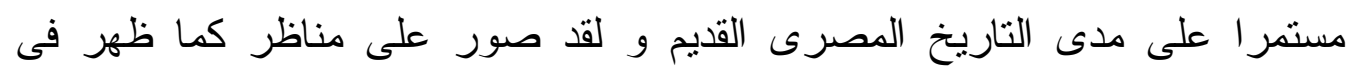

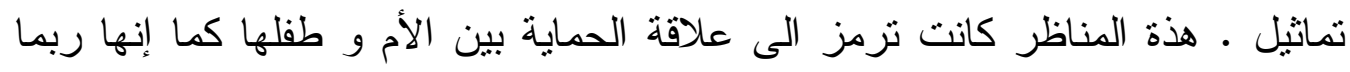

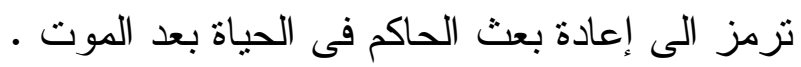

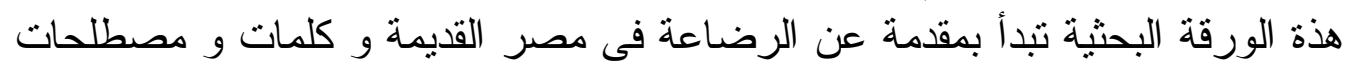

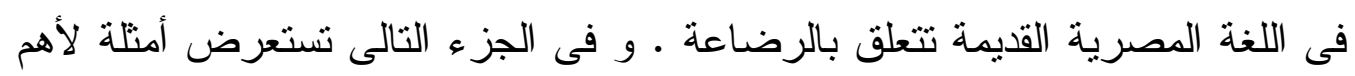

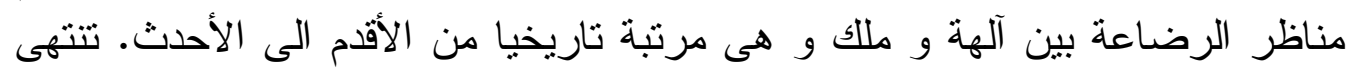

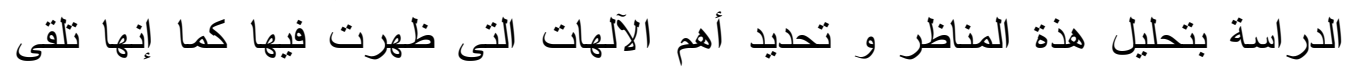

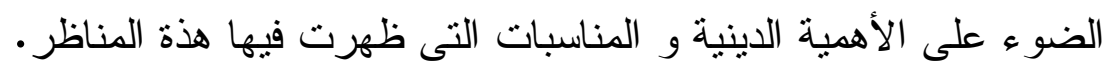




\section{دراسات في آثار الوطن العربي؛}

\section{INTRODUCTION}

In the first period of their lives, all mammals are dependent for survival on their mothers' milk as the only source of nourishment, they are assured protection from external dangers, stability and security. For humans as well, the breastfeeding has been the practice of all cultures at all times. The breast has become a symbol for nourishment, protection, consolation and existence

The ancient Egyptian culture was no exception, and all Egyptian women, from the most powerful goddess to the lowliest peasant, are represented in Egyptian art as nurturers of the young ${ }^{(1)}$.

A scene from the tomb of Niankhkhnum and Khnumhotep at Saqqara (Dynasty V) depicts a woman suckling her child while tending a fire piled with bread mold. In several fifth and sixth Dynasties tombs, a woman is shown seated on a cargo boat suckling a child. Another example is shown on an Ostrakon from Deir elMedina depicts a mother suckling her new born child in the special birth bower ${ }^{(2)}$, (pl. 1-a).

In statuary, there are several examples of nursing mothers as in the Middle Kingdom statuette of a women dressing hair of a nursing mother, exhibited in the Metropolitan Museum of Art $\boldsymbol{M M A}$ 22.2.35 ${ }^{(3)}$, (pl. 1-b). Another two Middle Kingdom examples show a mother breastfeeding her child, Berlin 9623 and Leipzig 1028 ${ }^{(4)}$. Such themes were even repeated among noblewomen as in the statuette of princess Sobek-Nakht nursing a prince dating back to Dynasty XIII, exhibited in the Brooklyn Museum n. 43.137 ${ }^{(5)}$. (pl. $1-c)$.

In the legend of Isis and Osiris, the two sisters Isis and Nephtys were described in the pyramid texts as mourning the deceased king

(1) Mistress of the House, Mistress of the Heaven: Women in Ancient Egypt, Brooklyn, 1996, p. 16.

(2) Robins, G., Women in Ancient Egypt, London, 1993, p. 11.

(3) Mistress of the Housae, op. cit., p. 59; www.metmuseum.org/collection/search-thecollections/100000442.

(4) Hornemann, B., Types of Ancient Egyptian statuary, vol. 5, Copenhagen, 1951, p. 1250.

(5) Mistress of the House, op. cit., p. 60. 


\section{دراسات في آثار الوطن العربيء 1}

and causing him to live again. They both suckle the king like a baby, thus assisting his rebirth and preparing him for eternal life. Isis was able to be impregnated by her husband and gave birth to Horus. Isis protected him when he was a child, her confinement and nurturing of her infant son took place in the marshes of the Delta. There is a reference in the pyramid texts to the ruler drinking milk from her breasts ${ }^{(6)}$.

Accordingly, the representation of Isis suckling Horus became a common theme in ancient Egyptian art, whether in statuary or scenes. This theme was adopted as well by other goddesses which will be discussed later on this paper.

\section{The Designation of suckling and nursing in the ancient} Egyptian language:

In the ancient Egyptian language, the word used to define the

female breast was mm

\section{mmn $\nabla m n d^{(8)}$,but Faulkner stated that $m n d$ is used for male's breast $^{(9)}$.}

The nursing or breastfeeding process was referred to by

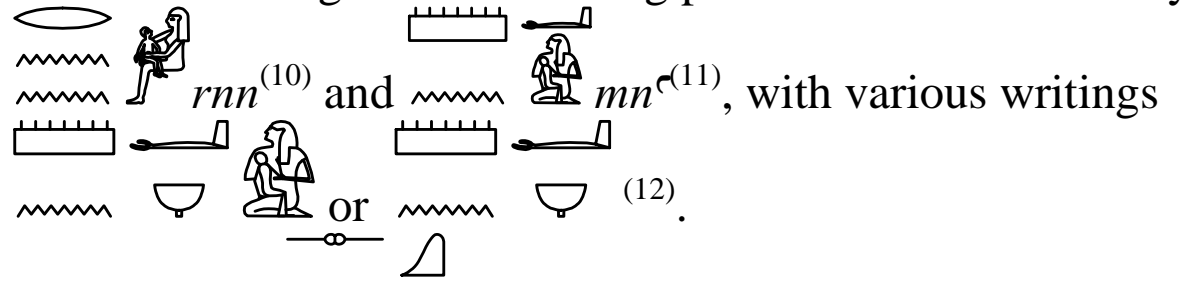

The word mum $\nabla$ snk is used as well to refer to suckling and

(6) Lesko, L., the Remarkable Women of Ancient Egypt, Berkeley, 1978, p. 165.

(7) Erman, A., and Grapow, H., Wörterbuch der Aegyptischen Sprache. Band II. Leipzig. 1940, pp. 92-93); Faulkner, R., A Concise Dictionary of Middle Egyptian, Oxford, 1964, p. 110.

(8) Gardiner, A., Egyptian Grammar, London, 1957, p. 569.

(9) Faulkner, op.cit., p. 110.

(10) Wb II, op. cit., pp. 436-437; Gardiner, op.cit, p. 578, 619; Faulkner, op.cit, p.150

(11) Gardiner, op. cit, p. 568; Faulkner, op. cit, p. 108.

(12) $\boldsymbol{W b}$ II, op. cit., p. 77. 

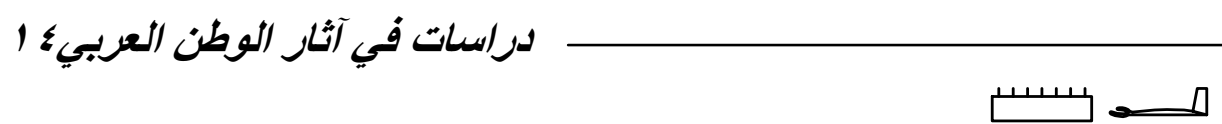

nursing ${ }^{(13)}$. As for the nurse, she was called $m n^{\top} t$ mmn $\square \nabla$,

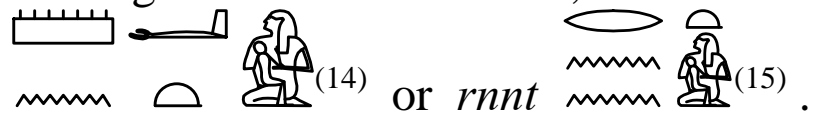

Examples of representations of a goddess suckling a king in Ancient Egypt:

Representations of a goddess suckling the king occur in Egyptian art as early as the Old Kingdom and continue throughout Egyptian history. In statuary, the earliest representation of a young child seated on the lap of an adult female is the Old Kingdom statuette of Pepy II (Dynasty VI), he is depicted as a miniature king seated on the lap of his mother, queen Ankhnesmeryre. It is known that Pepy ascended the throne as a child, and this statuette may commemorate the fact that the queen acted in some capacity as regent for her $\operatorname{son}^{(16)}$.

It is to be noted that representations in relief, depicting a lioness goddess embracing or suckling the king appeared since the reign of king Snefru (Dynasty IV) ${ }^{(17)}$.

Among the earliest depictions of a king suckled by a goddess a scene that comes from the valley temple of king Sahure in Abusir (Dynasty V), (pl. 2-a). It shows the king suckling from the goddess Nekhbet who is represented in a complete female form, she is wearing a tight-fitting dress and her head is surmounted with a vulture headdress. Her left arm is embracing a smaller figure of the king, while holding and offering her breast to the king's mouth. The king is holding the goddess from her right wrist and a holding a ' $n h$ sign in the left hand ${ }^{(18)}$. Another Old Kingdom example is a relief

(13) Wb IV, p. 174; Gardiner, op. cit., pp. 453, 591; Faulkner, op. cit., p. 234.

(14) Wb II, op. cit., p. 78; Gardiner, op. cit.p. 568; Faulkner, op. cit., p. 108.

(15) Wb, op. cit., pp. 436-437; Gardiner, op. cit, p. 578; Faulkner, op. cit., p. 150.

(16) Mistress of the House, op. cit., pp. 16-17.

(17) Sourouzian, H., "Features of Early Twelfth Dynasty Royal Sculpture", in: Bulletin of the Egyptian Museum. vol. 2, 2005, p. 106.

(18) Verner, M., The Pyramids: the Mystery, Culture and Science of Egypt Great Monuments, Cairo, 2000, p. 48; Budin, S., Images of Women and Child from the Bronze Age, Cambridge, 2011, p. 88. 


\section{دراسات في آثار الوطن العربيء 1}

from the valley temple of king Niuserre at Abusir. It depicts the king being suckled by the goddess Sekhmet, who is here depicted as a lion-headed female goddess. She is standing, embracing the king with her right arm and offering her breast with her left hand ${ }^{(19)}$. (pl. 2-b).

From the pyramid of king Unas at Saqqara (Dynasty V); a limestone fragment of raised relief (actually exhibited in the Egyptian Museum, Cairo) shows a goddess in the female aspect embracing the young king with her right arm, while holding and offering her breast to him with the left hand and placing her nipple between his lips. The king is portrayed in a smaller figure ${ }^{(20)}$.(pl. 2c).

A deteriorated scene from the funerary temple of king Pepy II (Dynasty VI) at Saqqara, shows him being suckled by female goddess which was assumed to be Wadjet ${ }^{(21)}$.

From the Middle Kingdom, a relief fragment from the funerary temple of Montuhotep Nebhepetre at Deir el-Bahari depicts the king suckling from the teats of the goddess Hathor in her bovine form $^{(22)}$.

The same king is depicted in a chapel at Dendara that he erected for the goddess Hathor. He is shown suckled two times by the goddess but in her female form (coronation scene) ${ }^{(23)}$.

Another Middle Kingdom example is a scene from a gold pectoral where the future king Amenemhat III is shown suckling from Hathor's udder, while an attendant gently strokes the goddess's neck $^{(24)}$.

It the New Kingdom, from the chapel of Hathor in the temple of

(19) Egyptian Art in the Age of the Pyramids, New York, 1999, p. 352; Verner, op. cit., p. 48; A Companion to Ancient Egypt, Malden, 2010, p. 64; Budin, op. cit., p. 88.

(20) Robins, G., The Art of Ancient Egypt, London, 2008, p. 58.

(21) Budin, op. cit., p. 52.

(22) Pinch, G., Votive offerings to Hathor, Oxford, 1993, p. 4; Budin, op. cit., p. 57, 63.

(23) Graves-Brown, C., Dancing for Hathor: Women in Ancient Egypt, London 2010, p. 166.

(24) Sharpes, D., K., Sacred Bulls Holly Cow, New York, 2006, p. 65. 


\section{دراسات في آثار الوطن العربي؛}

Hatshepsut at Deir el-Bahari, the queen is shown being nursed by Hathor. The goddess is depicted as a large cow, its head is surmounted by the Hathoric emblem: a sun disk between two cowhorns. Hatshepsut is shown at least quarter of the size of goddess, she is wearing the khephresh blue crown and kneeling below Hathor's rear legs, while holding one of the goddess udders and sucking from it ${ }^{(25)}$. (pl. 2-d).

A scene from the tomb of Thutmose III in the Valley of the kings (KV 34) represents the old symbol of Hathor - the sycamore tree goddess - suckling the king. He is portrayed holding with both hands a left arm that extends from the tree while suckling from a breast attached to one of tree's branches. The king is shown as an adult wearing the Khepresh blue crown with a frontal cobra. Hathor here is associated with Isis since the hieroglyphs accompanying the text mention Isis. Isis was also the name of Thutmose natural mother, so nurturing and protecting by Isis of her son Horus, equated with the living king, is graphically portrayed ${ }^{(26)}$. (pl. 2-e).

There are three statuettes representing king Amenotep $I$ as a child seated on the lap of the goddess Renenutet, two of which are in the Egyptian Museum, Cairo (JE 390376, JE 42002) ${ }^{(27)}$.

A similar scene to that of Hatshepsut, from the shrine of Hathor in Deir el-Bahari represents king Amenhotep II kneeling under the rear legs of the goddess Hathor in her bovine form and holding one of her udders and suckling from it. The goddess is shown walking out of the mountain of the necropolis while protecting a small statue of the king under her chin and also suckling the king as an infant $^{(28)}$.(pl. 3-a).

(25) Lesko, B., The Great Goddesses of Egypt, Norman, 1999, pp. 105-107; Sharpes, op. cit., p. 65 .

(26 Lesko, L., The Remarkable Women of Ancient Egypt, Berkeley, 1978, p. 7; Lesko, B., The Great Goddesses of Egypt, Norman, 1999, pp. 170-171; Cline, J., O'Connor, D., Thutmosis III: A New Biography, Michigan, 2006, p. 125.

(27) Budin, op. cit., p. 60.

(28) Ions, V., Egyptian Mythology, Verona, 1965, p. 65; Saleh, M., and Sourouzian, H., The Egyptian Museum, Cairo, Mainz, 1986, n. ; Shafer, B., E., Religion in Ancient Egypt, London, 1991, p. 16; D'Auria, S., Servant of Mut: Studies in Honor of Richard Fazzini, 


\section{دراسات في آثار الوطن العربي؛}

In a scene in the birth room of Luxor temple, (pl. 3-b), the infant king Amenhotep III and his ka (with side lock and finger to mouth) are portrayed upon the lap of two identical goddesses with doublefeather crowns and suckling from them. In front of each goddess, the cartouche of the king is carved. On the left side of the scene, the queen Mutemwia, the king's mother is shown crouching, and her hands are to her breasts ${ }^{(29)}$.

A pendant found inside the golden shrine of the tomb of Tutankhamun (pl. 3-c) depicts the king, in the Amarna artistic style, wearing the Khepresh blue crown and being suckled by the goddess Weret-Hekau shown as a human-headed cobra with breasts and arms ${ }^{(30)}$. Weret Hekau was the ancient Egyptian personification of supernatural powers. Her name means "great of magic"(31).

In the speos of Horemheb at Gebel el-Silsila, on the southern end wall, the young king is shown standing, wearing the khepresh blue crown and a short kilt. He is suckling from the left breast of the goddess Tawert, and holding her from her right forearm. The goddess is depicted in a rare human form, she is embracing the king with her left arm and offering him her breast with the right hand $^{(32)}$.(pl. 3-d).

In a scene from the temple of Seti I (Dynasty XIX) at Abydos, the king is portrayed standing while suckling at the breast of the goddess Mut, who is shown seated. With the left hand she holds the right breast to the lips of the king, while her right arm encircles the king's shoulders reaching down to the abdomen level. The king wears the Khepresh crown and the royal kilt ${ }^{(33)}$.

Leiden, 2008, p. 191.

(29) Budin, op. cit., p. 69.

(30) Eaton-Krauss, M., and Graefe, E., The Small Golden Shrine of Tutankhamun, Oxford, 1985, pl. VII; Hardwick, T., "The Iconography of the Blue Crown in the New Kingdom", in: JEA 89, 2003, p. 119.

(31) Lesko, B., The Great Goddesses of Ancient Egypt, Norman, 1999, p. 74.

(32) Porter, B., and Moss, R., Topographical Bibliography of Ancient Egyptian Hieroglyphic Texts, Reliefs and Paintings. V. Upper Egypt, Oxford, 1937, p. 208 (3); Forbes, D., C., "Monument Close-up:Speos Horemheb", in: KMT 4/2, 1993, pp. 48-49.

(33) Budin, op. cit., p. 79, fig. 3. 


\section{دراسات في آثار الوطن العربي؛ 1}

A painted limestone ostracon from Deir el-Medina, now in Cleveland Museum, is decorated with a scene of Ramses II being suckled by a goddess. (pl. 4-a). The king appears in child size, he is wearing the Khepresh crown and a short kilt. He is holding the crook and the flagellum in his left hand, and touching the goddess's right hand. The goddess is embracing the king with her left arm and about to nurse him. She is depicted in a complete female aspect, with a vulture's wig on her head ${ }^{(34)}$. It is to be mentioned that Maryam Ayad stated that the king depicted in this scene is Seti I and not Ramses II ${ }^{(35)}$.

On the southeast wall of the great Hypostyle Hall of the temple of Amun-Re at Karnak, Ramses II is shown as a prince with a distinctive side lock. He is being suckled by a female goddess, whom he is holding from the left forearm. The goddess is not identified as the head is destroyed. She is embracing the king with her right arm while offering him her breast with her left hand ${ }^{(36)}$.) (pl. 4-b).

In the temple of Ramses II at Beit el-Wali, Nubia, a symmetrical decoration is carved on the walls of the sanctuary's doorway. (pl. 4, c-d). In the south half, he is suckled by Isis, and in the north half by Anket ${ }^{(37)}$. In the latter, the goddess is represented in a complete female aspect. She is inclining to embrace a smaller figure of the king with her left arm reaching down to the abdomen level, while holding and offering her left breast to the king's mouth with her right hand. The king is depicted with a dark-skin color, he is wearing the Khepresh crown with a frontal cobra and a pleated kilt. $\mathrm{He}$ is holding a pear-shaped mace and a ${ }^{\top} h \underline{h}$ sign in his left hand,

(34) Mistress of the House, op. cit., p. 118; www.clevelandart.org

(35) Ayad, M., God's Wife, God's Servant: the god's wife of Amun, London, 2009, p. 126; id, "The Transition from Lybian to Nubian Rule: the role of the god's wife of Amun, in: The Lybian Period in Egypt: Historical and Culture Studies into the $21^{\text {st }}-24^{\text {th }}$ Dynasties, Leiden, 2009, p. 36.

(36) www.memphis,edu/hypostyle/southeasthalf-pl.67

(37) Török, L., Between the Two Worlds: the Frontier Region, between Ancient Nubia and Egypt, Leiden, 2009, p. 247. 


\section{دراسات في آثار الوطن العربيء}

while holding the goddess's right wrist with his right hand and raising his head to reach the goddess's nipple ${ }^{(38)}$.

From the Late Period, on the Bubastide portal of Amun-Re at Karnak, Sheshonq I is portrayed suckled by Hathor. The king is standing wearing the double crown and a short royal kilt, he is holding the goddess's right wrist with his left hand. Hathor is shown in a female aspect, offering her left breast with her right hand while encircling the king with her left $\operatorname{arm}^{(39)}$.

\section{Analysis:}

\section{Occasions in which the king was shown suckled by a goddess:}

It seems that the king was suckled by a goddess on three occasions: 1. At birth into this world, as in the scene of king Amenhotep III, where he and his Ka were suckled by two goddesses (pl. 3-b)

2. At coronation - his birth into kingship, as in the scene of king Mentuhotep Nebhepetre at Dendara where he is suckled two times by the goddess Hathor.

3. After his death, his rebirth in the afterlife. This explains in some scenes the black color of the king's skin, which refers to his resurrection and rebirth.

When being of non-royal blood, kings usually invented some sort of political propaganda to legitimize their rule, such as the Divine Birth. Accordingly, it has been noticed that these kings were keen on being represented suckling from a goddess to prove their legitimacy, as in the case of kings Sahure, Mentuhotep Nebhepetre in Dendara where he used the cult of Hathor to legitimize and emphasize his rule. This is the case as well oh Hatshepsut, Amenhotep III and others.

Goddesses related to the pharaoh's suckling process in Ancient Egypt:

From the previous depictions, it seems that the king's suckling process was related to certain goddesses, the most common was the

(38) Atlas of Egyptian Art, Cairo, 2000, p. 105.

(39) Fazzini, R., Egypt Dynasty $\boldsymbol{X} \boldsymbol{X I I - X X} \boldsymbol{V}$, Leiden, 1988, pl. VI. 


\section{دراسات في آثار الوطن العربيء}

goddess Hathor in her bovine form, sometimes also in a female form with a solar disk between two horns of a cow. Her first known appearance suckling the king dates back to the Middle Kingdom in the scene of king Montuhotep Nebhepetre at Deir el-Bahari. Her connection with the divine kingship is prominent in art and literature. Hathor had many roles, she was the divine patroness of music and dance. She was frequently portrayed as a cow and divine nurse who suckles the royal heir ${ }^{(40)}$.

To be shown suckling at the teats of this goddess emphasized not only the divine manifestation of the king - and thus his legitimacy, but also the role of Hathor and her milk in the rejuvenation for the living king and resuscitation of the dead king. In the inscription of the chapel of king Mentuhotep Nebhepetre at Dendara, the goddess claims to rejuvenate the king with her milk.

Another two important goddesses related to suckling are Nekhbet and Wadjet. Nekhbet was most commonly associated with the vulture form, also depicted as a woman with a vulture's head or a complete female form with a vulture headdress (as in Sahure's relief), (pl. 1-d). The ancient Egyptian vulture hieroglyph (read $m w t$ ) was the ideogram for mother ${ }^{(41)}$.Nekhbet, then, is the southern mother. The depiction of Nekhbet nursing Sahure has a number of significant themes: 1- Her milk provided the king with life, youth, and protection. 2- The goddess was related to motherhood, as his mother, he received life, protection, abundance and sovereignty. 3It is possible that Sahure used the suckling goddess to legitimize and emphasize his rule. Likewise, the scene of king Pepi II with the goddess Wadjet emphasizes the importance of the maternal role in the king's reign, in many ways the origins of his kingship.

The goddess Isis was a principal goddess related to suckling the ruling king (Horus). She was also mentioned in the Pyramid texts (as in utt. 42, \& 32b - utt. 268, \& 372) where she was associated not only to the suckling of her son but also to that of her husband.

(40) Lesko, L., The Remarkable Women of Ancient Egypt, Berkeley, 1978, p. 6.

(41) Lesko, B., The Great Goddesses of Egypt, Norman, 1999, p. 85. 


\section{دراسات في آثار الوطن العربي؛ 1}

The milk of Isis, according to the pyramid texts is an essential ingredient for the resuscitation of the deceased, thus assisting the rebirth of her husband and preparing him for eternal life ${ }^{(42)}$. From an early period, Isis's suckling Horus symbolized her pivotal role in the transmission of divine kingship. Each new king who succeeded to the throne was considered to be the living Horus, the incarnation of the son of Isis and Osiris. Isis was thus the symbolic mother of each king and one of his links to the divine world ${ }^{(43)}$.

One of the oldest Egyptian deities, also related to suckling is the goddess Sekhmet, whose name is derived from the Egyptian word shm which means power and is often translated as "the powerful one". She is depicted as a lioness or a lion-headed woman, and is closely associated with kingship. The pyramid texts( 262 and 2206) suggest that the pharaoh was conceived by the goddess Sekhmet ${ }^{(44)}$. Another goddess is Anket, the goddess of the cataracts of the lower Nile. Her name in Egyptian is ' nkt. She is depicted as a woman wearing on her head a modius from which stem ostrich feathers. Her name could mean the embracer, which might refer to her as a nurse $^{(45)}$.

One of the distinguishing goddesses related to suckling is the goddess Renenutet whose name means "she who rears", she was a cobra goddess of nursing or rearing children, fertility and protector of the pharaoh. She was known as the "nourishing snake", and she offered her protection to the pharaoh in the land of the dead. She was linked with Isis in her role as mother of Horus. She could be represented by various combinations of snake and woman, including a cobra-headed woman suckling a child ${ }^{(46)}$.

(42) Lesko, B., The Great Goddesses of Egypt, Norman, 1999, p. 161.

(43) Mistress of the House, op. cit., p. 127.

(44) Wilkinson, R., The Complete Gods and Goddesses of Ancient Egypt, Cairo, 2003, p. 181.

(45) Pinch, G., Egyptian Mythology: A guide to the Gods, Goddesses and Traditions of Ancient Egypt, Oxford, 2004, p. 186; Hart, G., The Routledge Dictionary of Egyptian Gods and Goddesses, Routledge, 2005, pp. 28-29.

(46) Pinch, op. cit., p. 185. 


\section{دراسات في آثار الوطن العربي؛ 1}

Position and size of the king related to the goddess suckling him:

The Egyptian used a status-based scale for relative sizing. That is to say, the most important individual in a scene was portrayed as largest in proportion to his or her status relative to other beings within a scene. Such considerations influence how a suckling king might be shown in relation to a nursing goddess. As an individual of lesser rank than the deities, he or she must appear in smaller guise than they ${ }^{(47)}$. Thus it is not surprising to find the king in all the suckling scenes represented in a smaller size than that of the goddess. In the majority of representations of the king suckling from a female figure, he is represented standing while suckling, while in the scenes of the goddess Hathor in the bovine form the king kneels below the goddess rear legs and suckles from the goddess. The female form goddess embraces the king with one arm, one can see the arm resting on the king's chest, while presenting a breast to the king, placing the nipple to his mouth, the king at the same time holds the goddess arm that is offering the breast.

\section{Clothing, Crowns, and Insignia of the suckled king:}

The suckled king usually wore the royal kilt, the khepresh blue crown on his dead. Sometimes, he held the royal insignia like the crook, the flail or the $n h$ sign.

\section{Conclusion:}

1. The representations of a goddess suckling a king were more common on scenes and objects than in statuary.

2. It seems that the king was suckled by a goddess on three occasions: At his birth, at his coronation, and at his death when he was reborn in the afterlife.

3. By the act of nursing, the goddess confers to the king life, protection, resurrection, she confirms the king as her son and thus emphasizes his legitimacy, and ratifies his divinity.

4. Among the reasons these representations were depicted was

(47) Baines, J., Visual and Written Culture in Ancient Egypt, Oxford, 2007, p. 167. 


\section{دراسات في آثار الوطن العربي؛ 1}

the need of the king to prove his legitimacy like king Sahure, Hatshepsut, Amenhotep III and others.

5. There were certain goddesses related to suckling a king in Ancient Egypt, the most common was the goddess Hathor especially in her bovine form, others were Isis, Nekhbet, Wadjet, Renenutet, Sekhmet, Anket, Taweret, Bastet, Weret Hekau and Renenutet.

6. The king being suckled by a goddess usually wore the royal kilt, the khepresh on his head and sometimes he held royal insignia like the crook, flail or the $" n h$ sign.

7. In suckling scenes, the king was usually standing not sitting. In the case of being suckled from Hathor in her bovine form, he was always kneeling and holding one of its udders.

8. When the suckled king is depicted with black flesh, it may indicate that he is deceased. The black color symbolizes renewal and rebirth. Accordingly, being suckled in the afterlife implies that the king will be resurrected and restored in life.

\section{Bibliography}

1. Atlas of Egyptian Art. Cairo. 2000.

2. Ayad, M., "The Transition from Libyan to Nubian Rule: the Role of the God's Wife of Amun", in: The Lybian Period in Eg

3. ypt: Historical and Culture Studies into the 21-24 Dynasties. Leiden. 2009.

4. Ayad, M., God's wife, God's Servant: the God's wife of Amun. London. 2009.

5. Baines, J., Visual and Written Culture in Ancient Egypt. Oxford. 2007.

6. Budin, S., Images of Women and Child from the Bronze Age. Cambridge. 2011.

7. Cline, H., O'Connor, D., Thutmosis III: A New Biography, Michigan, 2006.

8. D'Auria, S., Servant of Mut: Studies in Honor of Richard Fazzini. Leiden. 2007.

9. Eaton-Krauss, M., and Graefe, E., The Small Golden Shrine 


\section{دراسات في آثار الوطن العربي؛ 1}

from the Tomb of Tutankhamun. Oxford. 1985.

10. Egyptian Art in the Age of the Pyramids. New York. 1999.

11. Erman, A., and Grapow, H., Wörterbuch der Aegyptischen Sprache. Band II, IV. Leipzig. 1940.

12. Faulkner, R., A Concise Dictionary of Middle Egyptian. Oxford. 1964.

13. Fazzini, R., Egypt Dynasty XXII-XXV . Leiden. 1988.

14. Forbes, D., c., "Monuments Close-up", in: KMT 4/2. 1993. pp, 46-51.

15. Gardiner, A., Egyptian Grammar. London. 1957.

16. Graves-Brow, C., Dancing for Hathor: Women in Ancient Egypt. London. 2010.

17. Hardwick, T., "The Iconography of the Blue Crown in the New Kingdom", in: JEA 89. 2003. pp. 117-141.

18. Hornemann, B., Types of Ancient Egyptian Statuary. vol. V. Copenhagen. 1951.

19. Ions, V., Egyptian Mythology. Verona. 1968.

20. Lesko, B., The Great Goddesses of Egypt. Norman. 1999.

21. Lesko, L., The Remarkable Women of Ancient Egypt. Berkely. 1978.

22. Lloyd, A., B., A Companion to Ancient Egypt. Malden. 2010.

23. Mistress of the House, Mistress of the Heaven: Women in Ancient Egypt. Brooklyn. 1996.

24. Pinch, G., Egyptian Mythology: A guide to the Gods, Goddesses and Traditions of Ancient Egypt. Oxford. 2004. 25. Pinch, G., Votive Offerings to Hathor. Oxford. 1993. 26. Porter, B., and Moss, R., Topographical Bibliography of Ancient Egyptian Hieroglyphic Texts, Reliefs and Paintings. V. Upper Egypt, Oxford. 1937.

27. Quirke, S., Ancient Egyptian Religion. London. 1992.

28. Robins, G., The Art of Ancient Egypt. London. 2008.

29. Robins, G., Women in Ancient Egypt. London. 1993.

30. Saleh, M., and Sourouzian,H., The Egyptian Museum, Cairo.

Mainz. 1986. 


$$
\text { دراسات في آثار الوطن العربيء } 1 \text { أ }
$$

31. Shafer, B., E., Religion in Ancient Egypt. London. 1991.

32. Sharpes, D., K., Sacred Bull, Holy Cow. New York. 2006.

33. Sourouzian, H., " Features of Early Twelfth Dynasty Royal Sculpture", in: Bulletin of the Egyptian Museum, vol. 2, 2005, pp. 103-124.

34. Thomas, A., Egyptian Gods and Myths. Princes Risborough. 1986.

35. Török, L., Between the Two Worlds: the Frontier Region, between Ancient Nubia and Egypt. Leiden. 2009.

36. Verner, M., The Pyramids: The Mystery, Culture and Science of Egypt Great Monuments. Cairo. 2000.

37. Wilkinson, R., The Complete Gods and Goddesses of Ancient Egypt. Cairo. 2003. 


\section{دراسات في آثار الوطن العربيء}

Plate. 1

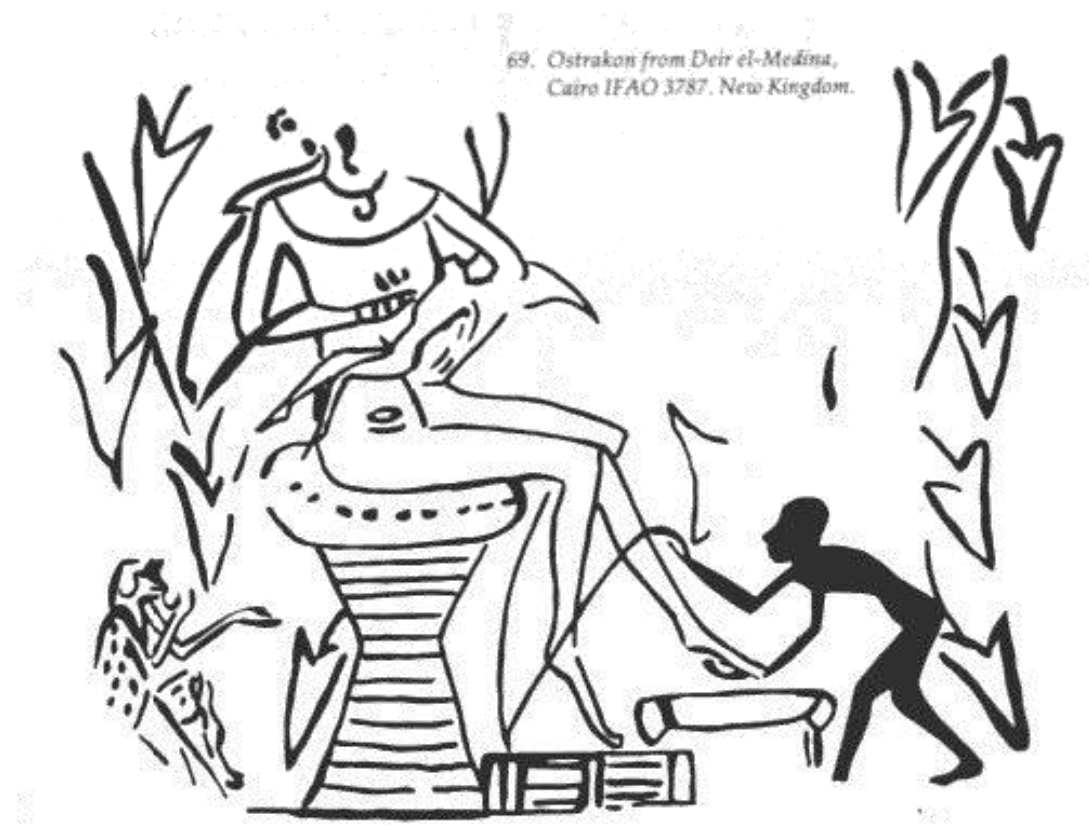

a: An Ostrakon a mother nursing her new born child in the birth bower Robins, G., Women in Ancient Egypt, London, 1993, p. 11

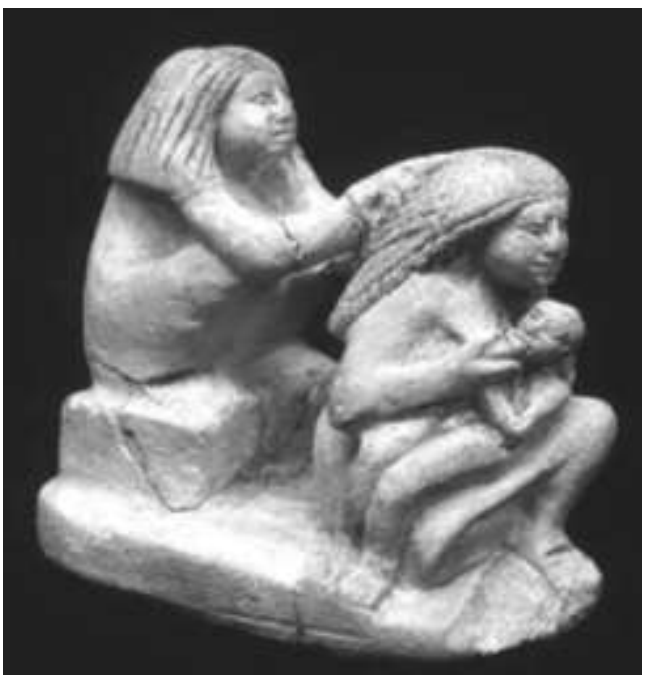

b: A statuette showing a woman dressing the hair of a nursing mother

www.metmuseum.org

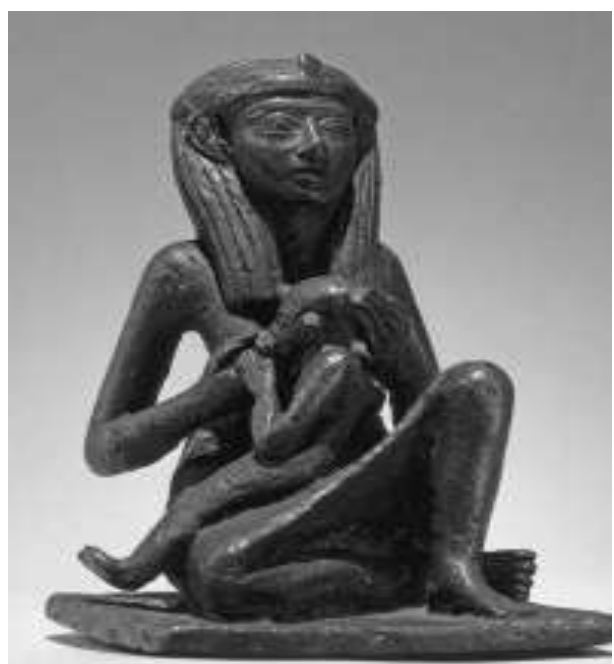

c: A statuette showing princess Sobek-Nakht nursing a prince.

Mistress of the House, Mistress of the Heaven, Women in Ancient Egypt, Brooklyn, 1996, p. 60.

Plate. 2 


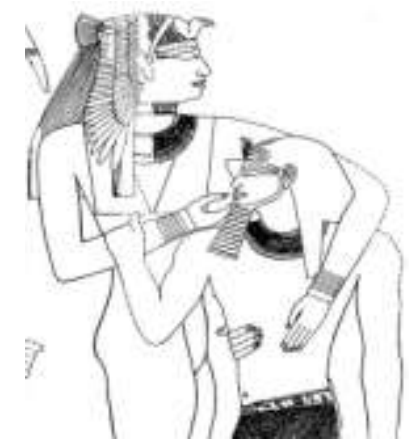

a: King Sahure being suckled by the goddess Nekhbet from Abusir

Verner, M., The Pyramids: the Mystery, Culture and Science of Egypt Great Monuments, Cairo, 2000, p. 48 www.flickr.com

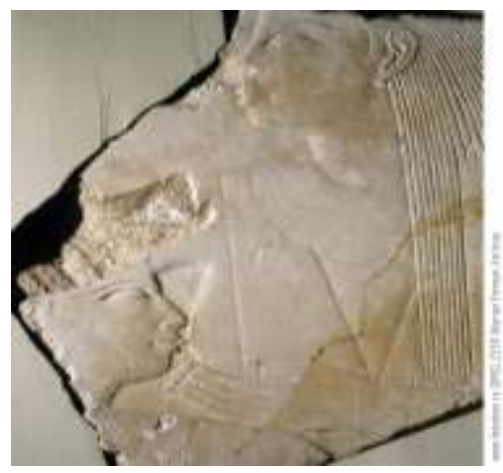

c: King Unas being suckled by afemale goddess from Saqqara

Robins, G., The Art of Ancient Egypt, London, 2008, p. 58.

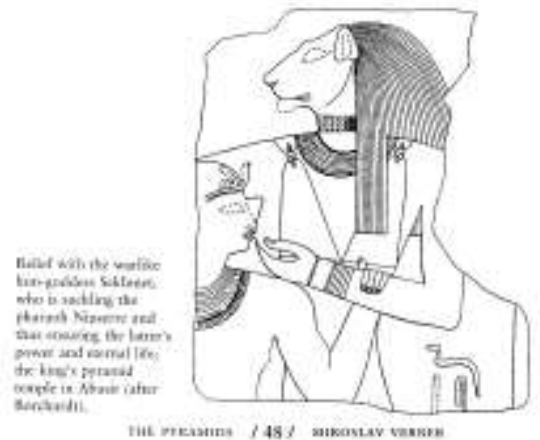

b: King Niuserre being suckled by the goddess Sekhmt from Abusir Ibid, p. 48.

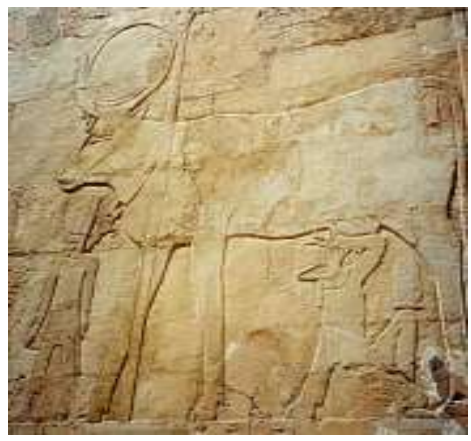

d: Hatshepsut suckling the goddess Hathor in her bovine form from Deir el-Bahari Lesko, B., The Great Goddesses of Egypt, Norman, 1999, p. 105?
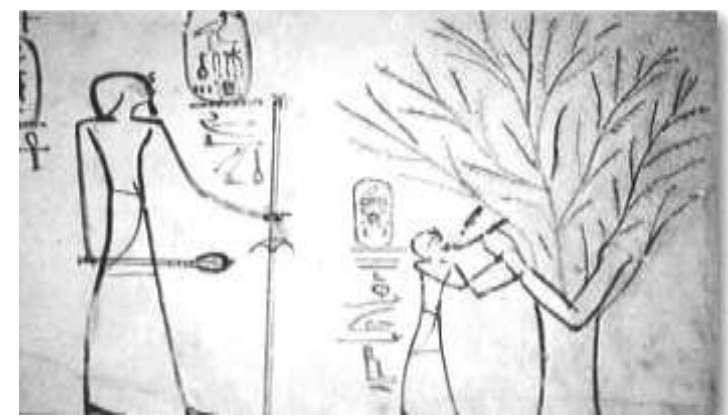

e: The Sycamore tree goddess Isis suckles king Thutmose III from his tomb in the Valley of the kings.

Plate. 3

Lesko, L., The remarkable Women of Ancient Egypt, Berkeley, 1978, p.7. 


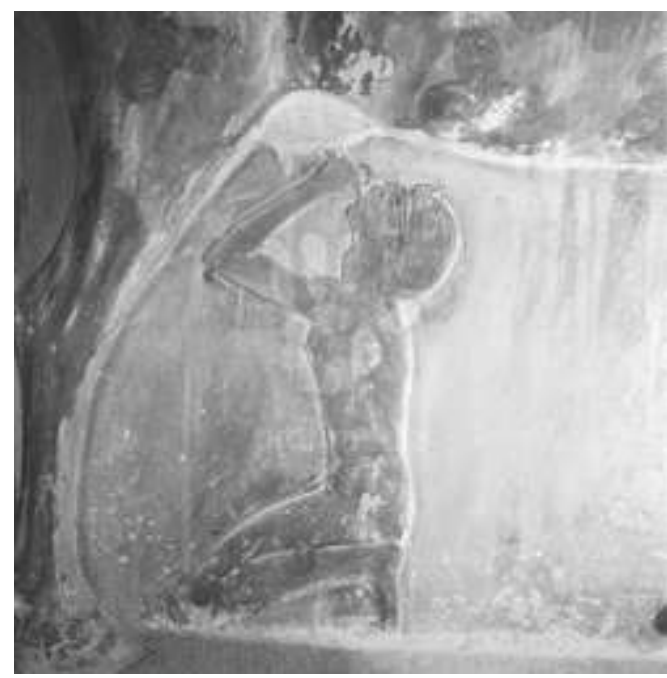

a: King Amenhotep II suckling from the udder of the goddess Hathor from Deir el-Bahari Ions, V., Egyptian Mythology, Verona, 1965, p. 65 .

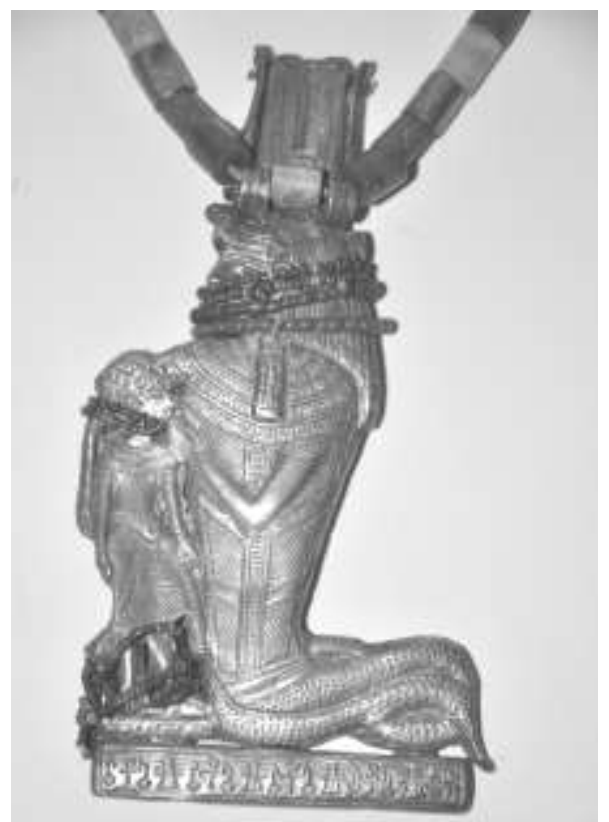

c: King Tutankhamun being suckled by the goddess Weret-Hekau

Eaton-Krauss, M., and Graefe, E., The Small Golden Shrine of Tutankhamun, Oxford, 1985, pl. VII.

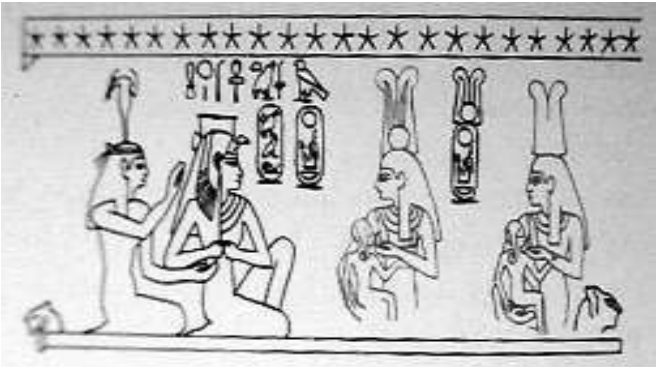

b: King Amenhotep III and his Ka being nursed by two goddesses from the birth room at Luxor temple. Budin, S., Images of Women and Child From the Bronze Age, Cambridge, 2011, p. 88.

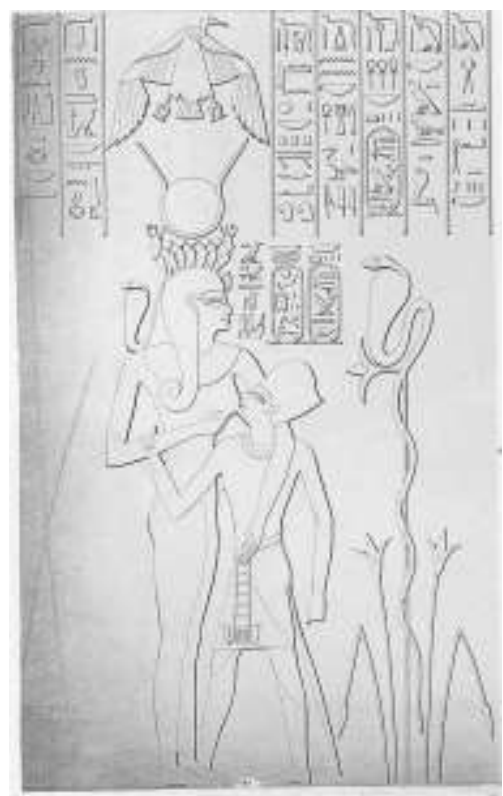

d: The goddess Tauret nursing king Horemheb from Gebel el-Silsila.

Forbes, D., C., "Monument Close-up: Speos Horemheb", in: KMT 4/2, 1993, pp. 48-49.

Plate. 4 


\section{دراسات في آثار الوطن العربي؛}

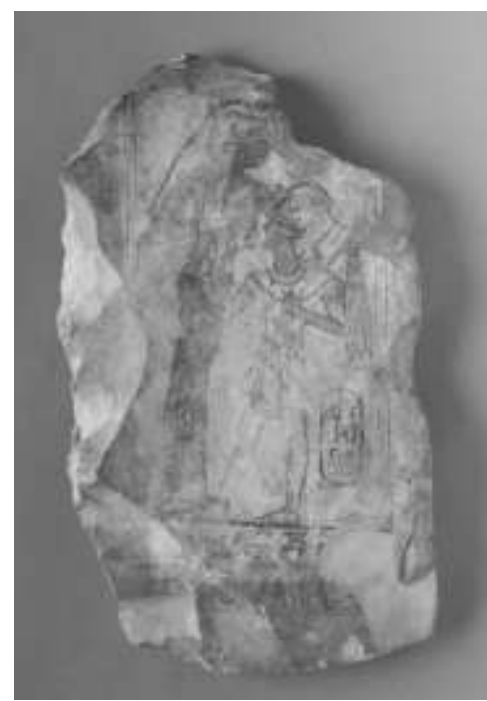

a: King Ramses II being suckled by a goddess.

www.clevelandart.org

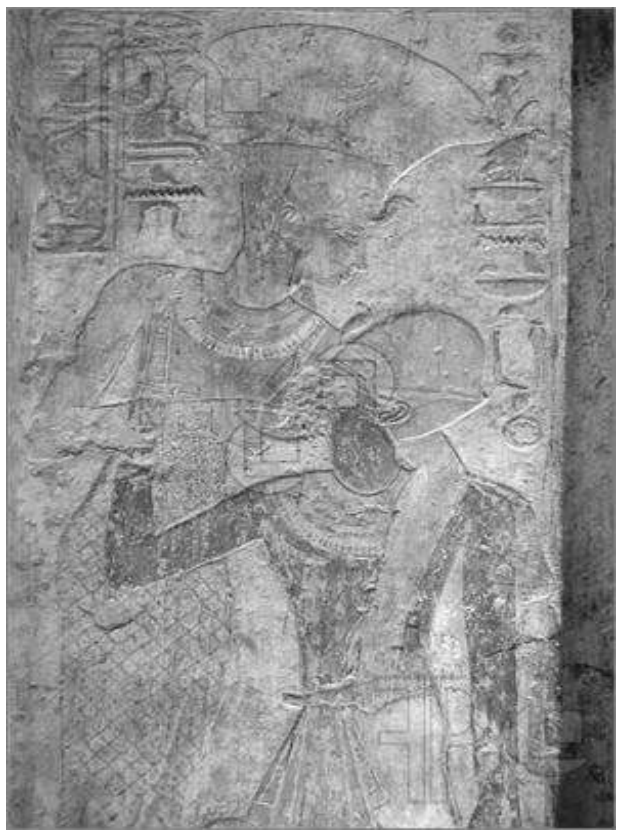

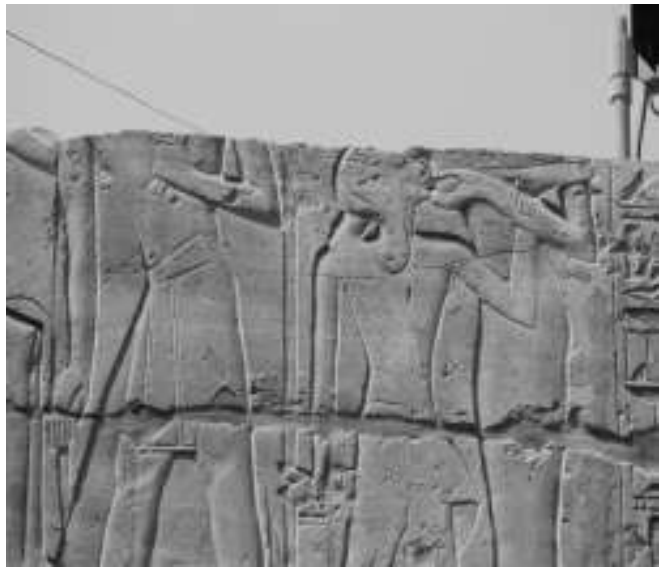

b: King Ramses II being suckled by a goddess in the great Hypostye Hall at Karnak temple. www.memphis.edu/hypostyle/southeasthalfpl.67

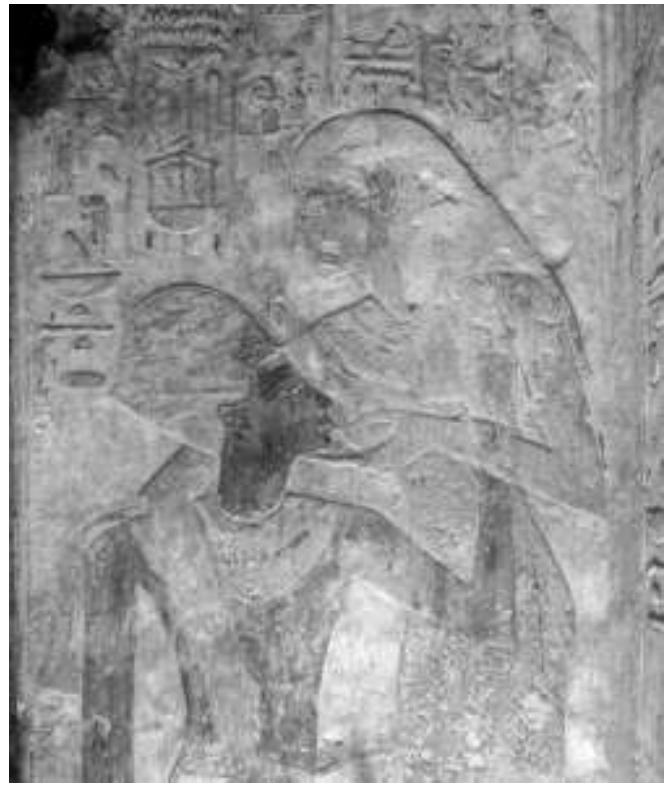

c-d: King Ramses II being suckled by the two goddesses Isis and Anket from the temple of Beit el-Wali.

Török, L., Between the two Worlds: the Frontier Region, between Ancient Nubia and Egypt, Leiden, 2009, p. 247. 